\title{
Potensi Bentonite Clay dan Karbon Aktif sebagai Aflatoksin Binders Berdasarkan Gambaran Imunologis dan Histopatologis pada Ayam Buras
}

\section{Effects of Bentonite Clay and Activated Charcoal as Aflatoxin Binders based on the Immunological and Histopathological Changes in Kampung Chicken}

\author{
Dhasia Ramandani $^{1)^{*}}$, Risa Ummami ${ }^{1)}$, Nurulia Hidayah ${ }^{1)}$, Naela Wanda Yusria Dalimunthe ${ }^{1)}$, \\ Soedarmanto Indarjulianto ${ }^{2)}$, Yanuartono ${ }^{2)}$, Alfarisa Nururrozi ${ }^{2)}$ \\ ${ }^{1)}$ Departemen Teknologi Hayati dan Veteriner, Sekolah Vokasi, Universitas Gadjah Mada, \\ Yogyakarta \\ ${ }^{2)}$ Departemen Ilmu Penyakit Dalam, Fakultas Kedokteran Hewan, Universitas Gadjah Mada, \\ Yogyakarta
}

Article history

Received: Feb 6, 2020;

Accepted: Mar 3, 2020

* Corresponding author:

E-mail:

dhasia.r@ugm.ac.id

DOI: https://doi.org/10.46549

/jipvet.v10i1.94

\begin{abstract}
Aflatoxin is a toxic compound from the fungus A. flavus which can cause a decrease in chicken productivity. This study aims to evaluate the effect of bentonite clay and activated charcoal in chicken feed as aflatoxin binders based on histopathological and immunological features in chickens. A total of 60 chickens were randomly divided into 4 groups (G0, G1, G2, and G3) each group consisted of 15 chickens. G0 as a control without the addition of aflatoxin to the feed. Groups G1, G2, and G3's feed were added with 106 ppb of aflatoxin. G2 was treated with $5 \mathrm{~g} / \mathrm{kg}$ bentonite clay, G3 was treated with $5 \mathrm{~g} / \mathrm{kg}$ activated charcoal. Chickens were vaccinated with Newcastle Disease (ND) on day 5. On days 14 and 28 serum was collected from the specimens for titer antibody testing. At the end of the study the chickens were dissected, the liver was taken for a histopathological test. The results of the aflatoxin level in the G0, G1, G2, and G3 groups were 10.5, 106, 19.1, and $23.95 \mathrm{ppb}$, respectively. Microscopic changes show the negative effects of aflatoxin on the liver organ. Group G0 did not show any histopathological changes, Group G2 and G3 showed several mild histopathological changes, whereas group G1 was the most severe. The antibody titers against Newcastle Disease (ND) of 4-weeks old chickens in G0, G1, G2, and G3 were $64,4,32,32 \mathrm{HI}$ units, respectively. The G0 treatment group has a protective titer against ND disease. Group G1 has the lowest (non-protective) ND antibody titer. Whereas the G2 and G3 groups both have protective titers against ND disease. Based on this study it was concluded that the administration of bentonite clay and activated charcoal was able to produce better immunological and histopathological features than the control group.
\end{abstract}

Keywords: Activated charcoal; Aflatoxin; Bentonite clay; Histopathological, Immunological

\section{PENDAHULUAN}

Ayam merupakan sumber protein utama bagi masyarakat Indonesia karena dapat menghasilkan telur dan daging (Palulungan, 2012). Mikotoksin merupakan substansi yang bersifat toksik pada manusia dan dapat menimbulkan kerugian yang besar pada hewan produksi (Oliveira et al., 2015). Data FAO menyebutkan bahwa sekitar $25 \%$ komoditas biji-bijian di dunia terkontaminasi jamur dan mikotoksin dan menjadi kerugian terbesar bagi industri peternakan di negara tropis (Bahri et al., 2005; Bintvihok et al., 2002). Jenis mikotoksin yang menjadi perhatian utama di bidang perunggasan adalah aflatoksin (Oliveira et al., 2015). 
Aflatoksin sebagian besar diproduksi oleh dua spesies jamur yaitu: Aspergillus flavus dan Aspergillus parasiticus. Kedua jenis jamur tersebut secara natural dapat tumbuh pada bahan pakan yang umum digunakan pada industri unggas seperti jagung dan gandum. Aflatoksin dapat mengakibatkan turunnya produktivitas ayam (Rachmawati, 2005; Bahri et al., 2005) dan dapat terakumulasi di daging, hati, dan telur (Fowler et al., 2015). Beberapa tipe aflatoksin yang teridentifikasi paling toksigenik diantaranya adalah adalah aflatoksin $\mathrm{B}_{1}\left(\mathrm{AFB}_{1}\right)$ kemudian diikuti oleh $\mathrm{B}_{2}, \mathrm{G}_{1}$, dan $\mathrm{G}_{2}$ (Rawal et al., 2010).

International Agency for Research on Cancer (IARC) mengklasifikasikan aflatoksin kedalam senyawa kelompok satu, yaitu senyawa yang bersifat karsinogenik pada manusia (Denli dan Okan, 2006; Rachmawati, 2005). Aflatoksin $B_{1}$ bersifat hepatotoksik, karsinogenik, neurotoksik, estrogenik, imunotoksik dan mutagenik (Fouad, A.M et al., 2019). Aflatoksin $B_{1}$ merupakan penyebab utama nomor tiga dari kanker hepar, terutama pada negara sub-Sahara Afrika dan negara berkembang di Asia (Fouad, A.M et al., 2019). Batas cemaran aflatoksin dalam makanan adalah sebesar $20 \mathrm{ppb}$ dan dalam susu sebesar 0,5 ppb (Widiastuti, 2014).

Mengingat begitu luasnya dampak negatif aflatoksin terhadap produktivitas unggas maupun kesehatan manusia, maka perlu dilakukan penelitian untuk mencari solusi permasalahan tersebut. Penelitian potensi pengikat aflatoksin (aflatoxin binder) perlu dilakukan secara komprehensif untuk mengetahui jenis dan efektifitasnya (Diaz et al., 2004). Pengikat aflatoksin yang banyak diteliti diantaranya adalah karbon aktif yang dapat digunakan untuk menyerap toksin pada kasus keracunan dan sebagai antidota universal (Widiyanti dan Maryam, 2016).

Pengikat racun yang berbasis clay secara umum dinyatakan aman oleh European Commission. Penggunaan clay pada pakan unggas juga berfungsi untuk meningkatkan flowability, mencegah caking, dan memperbaiki kualitas pelet. Akan tetapi, hingga saat ini tidak ada absorben yang telah disetujui oleh Food and Drug Administration (FDA) sebagai pencegahan atau pengobatan aflatoksin. Penelitian sebelumnya menyebutkan bahwa karbon aktif dengan ukuran partikel yang kecil terbukti dapat menurunkan aflatoksin pada ayam pedaging dibandingkan pada jenis mikotoksin yang lain (Widiyanti dan Maryam, 2016).

Penggunaan adsorben berbasis clay terbukti mampu mereduksi efek racun dari pakan yang telah terkontaminasi aflatoksin (Fowler et al., 2015). Bentonite merupakan adsorben aluminum silikat yang mampu menempel pada aflatoksin di saluran gastrointestinal agar racun tidak terserap. Kalsium bentonit merupakan absorben aflatoksin yang paling baik jika dibandingkan dengan sodium bentonit karena ion-ion kalsium dapat melakukan pemisahan pada lapisan clay daripada ion-ion sodium (Dixon et al, 2014). Penelitian ini dilakukan untuk mengetahui efek pemberian bentonite clay dan karbon aktif untuk menurunkan residu aflatoksin pada ayam kampung. Dengan mengetahui efektifitas bentonite clay dan karbon aktif sebagai aflatoksin binders, diharapkan dapat memberikan informasi kepada peternak ayam sehingga dapat meningkatkan produktivitas ternak ayam serta mengurangi kejadian aflatoksikosis pada ayam.

\section{MATERI DAN METODE}

Penelitian dilakukan di Laboratorium PreKlinis, Program Studi Diploma Kesehatan Hewan, Departemen Teknologi Hayati dan Veteriner, Sekolah Vokasi UGM dengan surat kelaikan etik oleh Komisi Etik Penelitian Fakultas Kedokteran Hewan UGM nomor: 0088/EC-FKH/Eks/2019. Data skor gambaran histopatologis dan titer antibodi dianalisa secara deskriptif.

\section{KULTUR A. FLAVUS}

Kultur isolat A. flavus FNCC 6019 dilakukan menggunakan Sabouraud Dextrose Agar (SDA) pada suhu $28^{\circ} \mathrm{C}$ selama 7 hari. Proses identifikasi A. flavus dilakukan secara kualitatif, yaitu dengan menggunakan slide culture lalu diamati karasteristik secara makroskopis dan mikroskopis.

\section{PEMBUATAN PAKAN EKSPERIMENTAL}

Pakan eksperimental terdiri dari jagung yang terkontaminasi aflatoksin, bekatul, dan konsentrat ayam (Istiqomah et al., 2017). Secara singkat, jagung direndam selama 
semalam, ditiriskan dan diautoklaf pada suhu $121{ }^{\circ} \mathrm{C}$ selama 55 menit. Biakan A. flavus yang telah ditumbuhkan, diambil konidia dan miseliumnya dengan metode scraping, kemudian dimasukkan dalam aquades hingga konsentrasi $5 \times 10^{7}$ konidia $/ \mathrm{mL}^{-1}$. Suspensi $A$. flavus diinokulasikan pada jagung steril, dan diinkubasi pada suhu $28^{\circ} \mathrm{C}$ selama 7 hari
(Abbas et al., 2006), kemudian dikeringkan dibawah sinar matahari dan dihomogenkan (Istiqomah et al., 2017). Jagung yang mengandung aflatoksin dicampur dengan bekatul dan konsentrat ayam untuk mendapatkan nilai nutrisi sesuai dengan Tabel 1 .

Tabel 1. Komposisi dan nutrisi pada bahan pakan eksperimental

\begin{tabular}{lccccc} 
Bahan pakan & Komposisi $(\boldsymbol{\%})$ & Protein $(\boldsymbol{\%})$ & Lemak (\%) & Abu (\%) & Serat kasar $(\%)$ \\
Jagung & 37.6 & 20.98 & 2.75 & 0.94 & 3.16 \\
Bekatul & 25.4 & 9.23 & 9.27 & 10.45 & 29.7 \\
Konsentrat & 37 & - & - & - & - \\
\hline
\end{tabular}

\section{MENGUKUR JUMLAH AFLATOKSIN}

Jumlah aflatoksin secara kualitatif diketahui dengan uji Enzyme-Linked Immunosorbent Assay (ELISA) menggunakan aflatoksin kit Veratox ${ }^{\circledR}$ menurut Wacoo et al. (2014). Pembacaan hasil uji menggunakan alat spektrofotometer dengan panjang gelombang $650 \mathrm{~nm}$ (Leszczynska et al., 2001)

\section{UJI IN VIVO}

Enam puluh ekor DOC ayam buras dibagi acak menjadi 4 kelompok perlakuan $(n=15$ ekor). Ayam dipelihara 60 hari dengan pemberian ransum sesuai standar nutrisi ayam kampung (Resnawati dan Bintang, 2000).

- Kelompok G0 (kontrol negatif): pakan komersial

- Kelompok G1 (kontrol positif): pakan komersial + aflatoksin $106 \mathrm{ppb}$

- Kelompok G2: pakan komersial + aflatoksin dosis $106 \mathrm{ppb}+$ bentonite clay 5 $\mathrm{g} / \mathrm{kg}$

- Kelompok G3: pakan komersial + aflatoksin dosis $106 \mathrm{ppb}+$ karbon aktif 5 $\mathrm{g} / \mathrm{kg}$

\section{UJI SEROLOGIS}

Ayam divaksinasi dengan Newcastle Disease (ND) pada hari ke 5. Pada hari ke 14 dan 28 serum dikoleksi untuk uji titer antibodi menggunakan uji hemaglutinasi inhibisi (HI) menurut Office International des Epizooties (OIE, 2000).

\section{NEKROPSI DAN PEMERIKSAAN} HISTOPATOLOGIS.

Pada akhir penelitian ayam dinekropsi. Organ hepar, tembolok, dan ginjal dikoleksi untuk pembuatan preparat histopatologis. Organ dianalisa secara makroskopis dengan metode skoring menurut Oliveira et al. (2015) kemudian difiksasi dengan larutan netral buffer formalin $10 \%$, dilakukan trimming, embedding, dan pengecatan dengan hematoksilin eosin.

\section{HASIL DAN PEMBAHASAN}

\section{KADAR AFLATOKSIN PADA PAKAN PERCOBAAN}

Kadar aflatoksin pada masing-masing kelompok dapat dilihat pada Tabel 2. Kecuali pada kelompok G1, seluruh pakan masih dalam batas aman menurut SNI 8173.3:2015, yaitu tidak lebih dari $50 \mathrm{ppb}$. Formulasi pakan G1 yang dikultur isolat $A$. flavus memiliki kadar total aflatoksin berbeda signifikan $(\mathrm{P}<0.05)$ dibandingkan dengan pakan yang diberikan perlakuan bentonite clay dan karbon aktif (G2 dan G3). Cemaran aflatoksin pada pakan komersial dapat ditemukan dengan persentase kejadian sebesar $70 \%$ dengan kadar yang bervariasi (Bahri et al., 2005). Cemaran ini dapat terjadi pada proses penyimpanan maupun pendistribusian pakan dalam periode yang terlalu lama. Pencegahan kontaminasi aflatoksin pada pakan komersial dapat dilakukan dengan penyimpanan sistem first in first out . 
Tabel 2. Jumlah aflatoksin total pada pakan eksperimental.

\begin{tabular}{|cc}
\multicolumn{1}{c|}{ Kelompok Perlakuan } & Rerata Kadar Alfatoksin (ppb) \\
G0 (tanpa alfatoksin) & 10.5 \\
G1 (aflatoksin 106 ppb) & 106 \\
G2 (aflatoksin 106 ppb + bentonite clay) & 19.1 \\
G3 (aflatoksin 106 ppb + karbon aktif) & 23.95 \\
\hline
\end{tabular}

Kadar total aflatoksin kelompok G2 dan G3 yang lebih rendah dari G1 diyakini disebabkan oleh penambahan bentonite clay dan karbon aktif. Bentonite clay dapat menurunkan aflatoksin hingga $66 \%$ dari konsentrasi primer yang menunjukkan kapasitas penyerapan bentonite terhadap aflatoksin. Hal ini mirip penelitian yang dilakukan Moosavi (2017), bahwa bentonit mampu mengikat aflatoksin hingga $89 \%$. Jumlah yang direkomendasikan pada pemberian bentonit adalah $0,05-0,3 \%$ dari total pakan sebagai pengikat mikotoksin. Bentonit yang diberikan lebih dari $0,5 \%$ dapat menurunkan mineral mangan, berinteraksi dengan koksidiostat dan obat yang lain, namun tidak mengikat vitamin. Bentonit terbukti dapat menurunkan aflatoksin dalam susu (Widiyanti dan Maryam, 2016).

Karbon aktif dapat menurunkan aflatoksin hingga $77,4 \%$ dari konsentrasi primer yang menunjukkan kapasitas penyerapan karbon aktif terhadap aflatoksin. Tingginya konsentrasi dan mekanisme penyerapan dan proses pengikatan karbon aktif terhadap mikotoksin tergantung dari sumber bahan, permukaan area dan distribusi ukuran pori (Huwig et al., 2001; Avantaggiato et al., 2004). Karbon aktif banyak digunakan sebagai antidota universal yang banyak digunakan dalam pengobatan untuk menyerap toksin pada kasus keracunan (Avantaggiato et al., 2007). Karbon aktif memiliki kekurangan yaitu dapat menyerap nutrisi penting dalam pakan seperti vitamin dan mineral, sehingga penggunaannya sebagai aflatoksin binders perlu dicari konsentrasi yang sesuai.

\section{PENGAMATAN HISTOPATOLOGIS}

Perubahan mikroskopik menunjukkan adanya perbedaan tiap kelompok dengan dan tanpa pemberian aflatoksin binders (Tabel 3). Perubahan mikroskopis menunjukkan efek negatif aflatoksin terhadap organ hepar. Kelompok G0 tidak ditemukan adanya perubahan histopatologis. Kelompok G2 dan G3 menunjukkan perubahan histopatologis paling ringan, sebaliknya kelompok G1 yang paling parah. Hasil dari penelitian mengindikasikan adanya efek hepatotoksik aflatoksin dengan adanya disorganisasi dan vakuolisasi sel hepatosit dengan berbagai derajat keparahan pada seluruh kelompok.. Perubahan pada hepar ini sesuai dengan penelitian yang dilakukan oleh Oliveira et al. (2015).

Tabel 3. Perubahan mikroskopis pada hepar

\begin{tabular}{|c|c|c|c|c|}
\hline Lesi mikroskopis & G0 & G1 & G2 & G3 \\
\hline Disorganisasi hepatosit & - & +++ & ++ & + \\
\hline Vakuolisasi hepatosit & - & +++ & - & + \\
\hline Hiperplasia duktus biliverus & - & +++ & - & - \\
\hline Hemorrhagi periportal & - & ++ & - & - \\
\hline Kongesti pada lobular vena sentralis & - & +++ & - & - \\
\hline Nekrosis periportal & - & ++ & - & - \\
\hline Dilatasi pada kapiler & - & +++ & - & ++ \\
\hline
\end{tabular}

Keterangan: tidak ada lesi (-), lesi ringan (+), lesi moderat (++), lesi berat/parah (+++) 

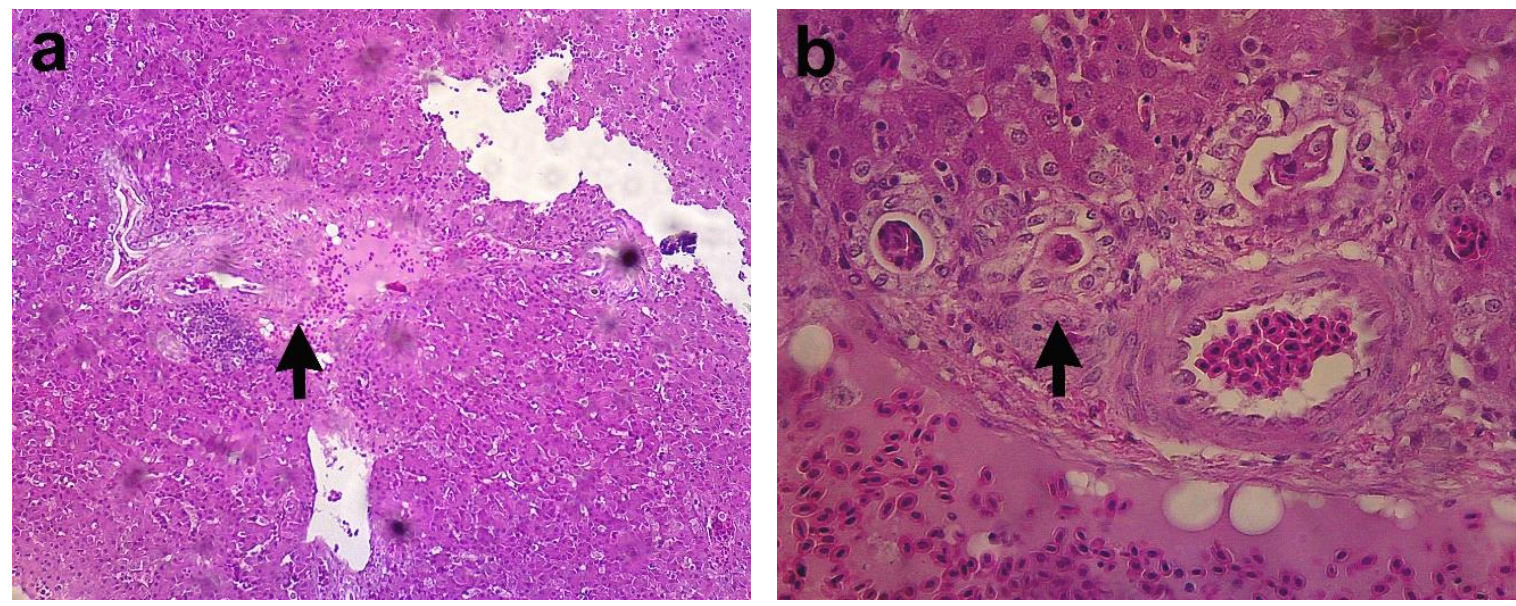

Gambar 1. Perubahan histopatologis hepar pada kelompok G1. (a) hiperplasia (anak panah) pada duktus biliverus (10x); (b) proliferasi (anak panah) duktus biliverus (40x).

Aflatoksin dapat menyebabkan keracunan dan dapat memiliki zat kimia yang dapat menyebabkan kanker, serta dapat menyebabkan kerusakan hepar (Moosavi, 2017). Efek akut dari aflatoksin pada hepar ayam adalah proliferasi atau hiperplasia duktus biliverus, vakuolisasi, infiltrasi lemak, dan hipertrofi sel hepar. Selain itu, aflatoksin juga dapat menyebabkan steatosis, akumulasi lemak, dan nekrosis (kematian sel hepar) (Istiqomah et al., 2017). Pada kelompok G2 yang ditambahkan dengan bentonite clay, mengalami penurunan tingkat keparahan patologis. Hal ini sesuai dengan penelitian yang dilakukan oleh Olvera et al. (2012) yang menjelaskan bahwa pemberian bentonit lebih protektif dibandingkan zeolit berdasarkan perubahan histopatologi hepar. Penelitian lain oleh Widiyanti dan Maryam (2016) memaparkan bahwa pemberian bentonit pada ayam pedaging yang diinfeksi mikotoksin memiliki kadar enzim Aspartate Aminotrasferase (AST) yang lebih baik dibanding kelompok kontrol.

Kelompok G3 yang ditambahkan dengan karbon aktif mengalami disorganisasi dan vakuolisasi hepatosit yang ringan $(+)$. Karbon aktif yang ditambahkan dengan aluminosilikat dapat menyerap $88 \%$ aflatoksin B1, $44 \%$ zearalenon, $29 \%$ fumonisin dan $29 \%$ okratoksin. Aflatoksin B1 dan zearalenon lebih besar persentase absorpsinya karena bersifat hidrofobik (Avantagiatto et al., 2007). Feed Consumption Rate (FCR) pada ayam pedaging menunjukkan hasil yang baik terhadap pemberian karbon aktif sebagai bahan pengikat aflatoksin dan trikotesena. Karbon aktif lebih efektif untuk mengurangi aflatoksin dibandingkan dengan trikotesena. Hal ini dimungkinkan karena efek protektif tergantung pada molekul toksik dari mikotoksin tertentu dan reaksi kimia dalam saluran gastrointestinal (Widiyanti dan Maryam, 2016).

\section{PENGAMATAN SEROLOGIS}

Hasil penelitian yang dilakukan menunjukkan bahwa titer antibodi terhadap Newcastle Disease (ND) pada kelompok perlakuan G0 memiliki titer protektif terhadap penyakit ND. Kelompok G1 memiliki titer antibodi ND yang paling rendah (tidak protektif). Sedangkan kelompok G2 dan G3 memiliki titer protektif terhadap penyakit ND (Gambar 2). Fungsi aflatoksin binders terhadap titer antibodi bersifat tidak langsung. Kontaminasi aflatoksin pada ayam dapat menyebabkan kerusakan organ limfoid primer (bursa fabrisius dan timus). Akibatnya titer antibodi hasil vaksinasi yang dihasilkan organ limfoid tidak mencapai level protektif yang diharapkan. Dengan demikian, mencegah ayam terkena aflatoksikosis dengan menggunakan aflatoksin binders dapat pula dikatakan mencegah kegagalan vaksinasi akibat titer antibodi yang dihasilkan rendah (Fowler et al., 2015). 


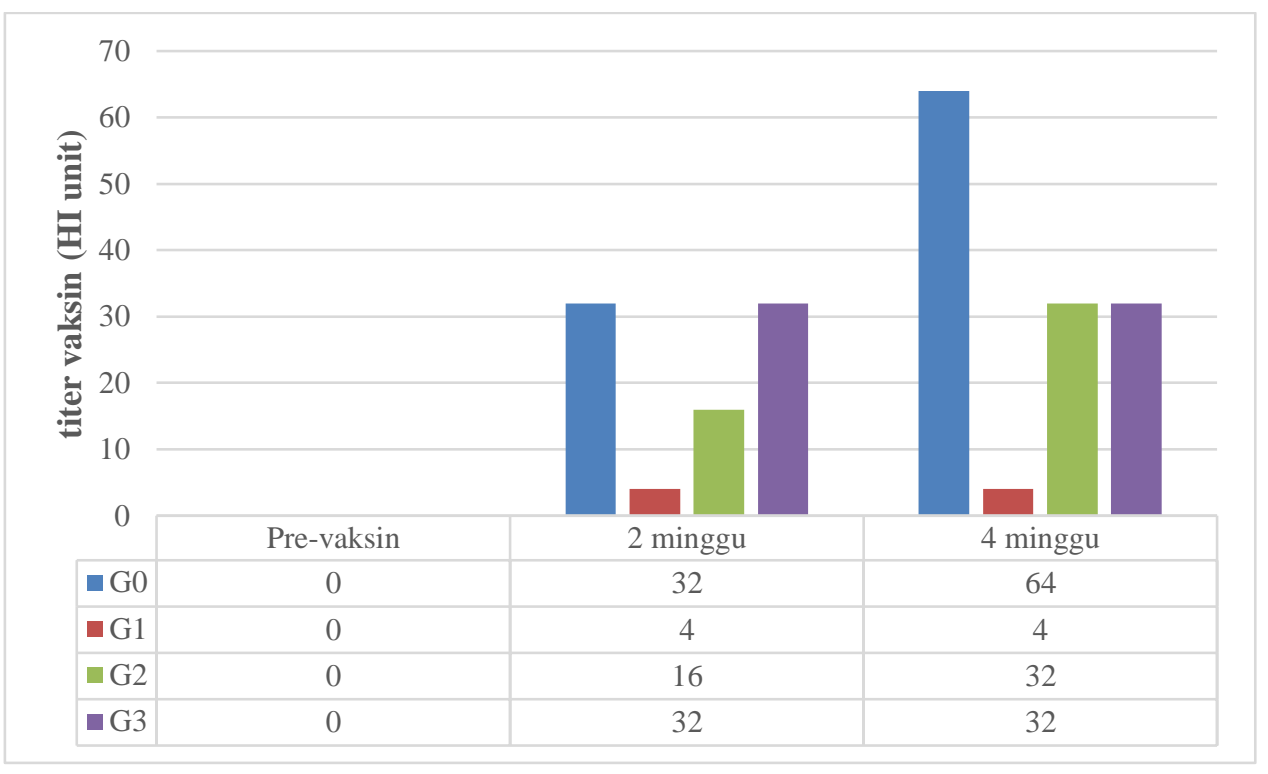

Gambar 2. Titer HI sebelum dan sesudah vaksin Newcastle Disease

\section{KESIMPULAN}

Bentonite clay dan karbon aktif mampu meningkatkan imunitas dan mampu menurunkan kadar aflatoksin dalam pakan. Perlu dilakukan penelitian lebih lanjut mengenai kombinasi aflatoksin binders.

\section{DAFTAR PUSTAKA}

Abbas, H.K., Zablotowicz., Bruns, H.A., dan Abel, C.A. 2006. Biocontrol of aflatoxin in corn by inoculation with non-aflatoxigenic Aspergillus flavus isolate. Biocontrol Science and Technology. 16(5), 437-449.

Avantaggiato G., Havenaar R., dan Visconti A. 2004. Evaluation of the intestinal absorption of deoxynivalenol and nivalenol by an in vitro gastrointestinal model, and the binding efficacy of activated carbon and other adsorbent materials. Food Chem Toxicol. 42:817824.

Avantaggiato G., Havenaar R., dan Visconti A. 2007. Assessment of the multi-mycotoxinbinding efficacy of a carbon/aluminosilicate-based product in an in vitro gastrointestinal model. J Agric Food Chem. 55:4810- 4819.

Bahri, S., Maryam, R., dan Widiastuti, R. 2005. Cemaran aflatoksin pada bahan pakan di beberapa daerah Propinsi Lampung dan Jawa Timur. JITV. 10(3), 236-241.

Bintvihok, A, S. Thiengnin, K. Dol dan S. Kumagai. 2002. Residues of aflatoxins in the liver, muscle and eggs of domestic fowl. J. Vet. Med. Sci. 64 (11): 1037 1039.

Denli, M. dan Okan, F. 2006. Efficacy of different adsorbents in reducing the toxic effects of aflatoxin B1 in broiler diets. South African Journal of Animal Science. 36 (4). 201-208.

Diaz, D.E., Hagler,W.M., Blackwelde, J.T., Eve, A.J., Hopkins, B.A., Whitlow, L.W. 2004. Aflatoxin Binders II: Reduction of aflatoxin $\mathrm{M} 1$ in milk by sequestering agents of cows consuming aflatoxin in feed. Mycopathologia. 157: 233-241.

Dixon, J.B., Barrientos-Velazquez, A.L., and Deng, Y. 2014. Aflatoxin control: safeguarding animal feed with calcium smectite. American Society of Agronomy and soil science society of America: Madison, WI, USA, pp. 11-16.

Fouad, A.M., Ruan, D., El-Senousey, H.K., Chen, W., Jiang, S., and Zheng, C. 2019. Harmful effects and control strategies of aflatoxin $\mathrm{B}_{1}$ produced by Aspergillus flavus and Aspergillus parasiticus strains on poultry: Review. Toxins. 11 (176), 1-21.

Fowler, J., Li, W., and Bailey, C. 2015. Effect of a calcium bentonite clay in diets containing aflatoxin when measuring liver residues of aflatoxin $B_{1}$ in starter broiler chicks. Toxins. 7:3455-3464.

Huwig A, Freimund S, Käppeli O, Dutler H. 2001. Mycotoxin detoxication of animal 
feed by different adsorbents. Toxicol Lett. 122:179-188.

Istiqomah, L., Damayanti, E., Julendra, H., Suryani, A.E., Sakti, A.A., dan Anggraeni, A.S. 2017. Effect of methionine and lactic acid bacteria as aflatoxin binder on broiler performance. AIP Conference Proceedings. 1854, 020017.

Leszczynska, J., Maslowska, J., Owczarek, A., and Kucharska, U. 2001. Determination of Aflatoxins in Food Products by the ELISA Method. Czech J. Food Sci. 19(1):8-12.

Moosavi, M. 2017. Bentonite clay as a natural remedy: a brief review. Iran $J$ Public Health, 46(9), 1176-1183.

OIE. 2000. OIE Manual of Standards for Diagnostic Test and Vaccines. $4^{\text {th }}$ ed. Paris.

Oliveira, A.A., Keller, K.M., Deveza, M.V., Keller, L.A.M., Dias, E.O., MartiniSantos, B.J., Leitao, D.F.G.M., Cavaglieri, L.R., dan Rosa, C.A.R. 2015. Effect of three different anti-mycotoxin additives on broiler chickens exposed to aflatoxin $\mathrm{B}_{1}$. Arch Med Vet, 47, 175-183.

Olvera, J.E.V, Garcia, H.A, Hernandez, A.B, Vergara, N.V.P, Moroyoqui, F.J.C. 2012. Evaluation of pathological effects in broilers during fumonisins and clays exposure. J Mycopathologia. 174: 247254.

Palulungan, J.A. 2012. Pengaruh penggunaan tepung singkong dan tepung ulat limbah kelapa sawit terhadap penampilan ayam pedaging fase starter. Jurnal Ilmu Peternakan dan Veteriner Tropis. 7 (1): 16-19.

Rachmawati, S. 2005. Aflatoksin pada pakan di Indonesia: Persyaratan kadar dan peratuan perundang-undangannya. Wartazoa. 4 (1): $26-35$.

Rawal, S., Kim, J.E., and Coulombe Jr, R. 2010 Aflatoxin $\mathrm{B}_{1}$ in poultry: Toxicology, metabolism and prevention. Res Vet, 89, 325-331.

Resnawati, H. dan I.A.K. Bintang. 2005. Produktivitas ayam lokal yang dipelihara secara intensif. Prosiding Lokakarya Nasional Inovasi Teknologi Pengembangan Ayam Lokal. Semarang, 25 Agustus 2005. pp. $121-125$.

SNI. 2015. Pakan ayam ras pedaging SNI 8173.3:2015. BSN. Jakarta.

Wacoo, A.P., Wendiro, D., Vuzi, P.C., and Hawumba, J.F. 2014. Methods for Detection of Aflatoxins in Agricultural Food Crops. Journal of Applied Chemistry. 14:1-15.

Widiastuti, R. 2014. Residu aflatoksin dan metabolitnya pada berbagai produk pangan asal hewan dan pencegahannya. Wartazoa, 24 (4), 179-190.

Widiyanti, P.M dan Maryam, R. 2016. Pemanfaatan bahan pengikat mikotoksin untuk menanggulangi kontaminasinya dalam pakan. Wartazoa, 26(2), 91-101 